\title{
EWOLUCJA USTROJU M. ST. WARSZAWY A PERSPEKTYWA NOWEJ REFORMY ORGANIZACYJNEJ
}

\section{SYSTEMIC EVOLUTION OF THE CAPITAL CITY OF WARSAW TOWARDS NEW ORGANIZATIONAL REFORM}

\section{Streszczenie}

Warszawa często doświadcza zmian organizacyjnych. Utrudnieniem dla budowania wspólnoty lokalnej jest bliskość politycznego centrum decyzyjnego. Oddziaływanie interesów partyjnych nie sprzyja decentralizacji i rozwojowi. Nie wypracowano optymalnej konstrukcji organizacyjnej. Ostatnia zmiana ustrojowa z 2002 r. jest przykładem recentralizacji władzy publicznej. W perspektywie nowej reformy należy uwzględnić dotychczasowe doświadczenia i wyeliminować niebezpieczeństwo realizacji doraźnych interesów.

Słowa kluczowe: transformacja systemowa; samorząd lokalny; ustój Warszawy; decentralizacja; reforma.

\footnotetext{
Abstract

Warsaw is often experiencing the organizational changes. Obstacle for building a local community is the proximity to the center of political decision-making. The influence of interests of political parties is not conducive to decentralization and
} 
development. Nor has been implemented the optimal organizational structure. The last change of local system, implemented in 2002 is an example of recentralisation of public authority. With a view to the new reform we must take into account past experience and eliminate the risk of implementing short-term interests.

Keywords: systemic transformation; local self-government; local system of Warsaw; decentralization; reform.

\section{Wprowadzenie}

Warszawa na tle polskich miast może być postrzegana z punktu widzenia funkcjonowania samorządu lokalnego jako specyficzny i wyjątkowy podmiot. Specyfika ta wiąże się w oczywisty sposób z funkcją stolicy, wyznaczoną na mocy artykułu 29 Konstytucji RP ${ }^{1}$. De facto, jest to jedyne prawnie wyróżnione miasto w Polsce, którego ustrój jest uregulowany na podstawie tzw. specustawy. Warszawa jest niewątpliwie centrum życia politycznego kraju, w którym splatają się ze sobą organy władzy państwowej, władzy samorządowej i interesy największych partii politycznych. Bliskość politycznego centrum decyzyjnego nie może być obojętna dla sposobu organizacji i działania lokalnego samorządu. Jednocześnie, trudno jest tu mówić o utrwalonej, specyficznej wspólnocie lokalnej, czy regionalnej w świetle licznych zmian demograficznych, zarówno wynikających z tragicznych doświadczeń II wojny światowej jak i z późniejszych ruchów migracyjnych (w szczególności o charakterze ekonomicznym).

Na poziomie krajowym, polityczno-decyzyjnym dostrzec można wyraźne zainteresowanie organizacją funkcjonowania miasta, co przejawia się w wyjątkowej częstotliwości wprowadzania szeroko zakrojonych reform organizacyjnych w całym okresie transformacji systemowej. Badania nad warszawskim samorządem lokalnym opieram w znacznej mierze na własnej obserwacji uczestniczącej w strukturach samorządu lokalnego. Od 1998 roku, przez 12 lat pełniłem funkcję radnego gminy Targówek m. st. Warszawy (później dzielnicy), wiceburmistrza, a także pracownika administracji samorządowej. Działalność ta była istotnym, praktycznym uzupełnieniem mojej pracy naukowej i dostarczyła sporo ciekawego materiału empirycznego.

Warto zwrócić uwagę na to, iż samorząd warszawski w nieznacznym stopniu znajduje się w obszarze zainteresowania naukowego. Wyjątkowe na tym

1 Konstytucja Rzeczypospolitej Polskiej z dnia 2 kwietnia 1997 r. (Dz.U. z 1997 r. Nr 78, poz. 483 ze zm.). 
tle są jednak znane nazwiska zmarłych niedawno dwóch profesorów, Michała Kuleszy² i Jerzego Regulskiego ${ }^{3}$, którzy wraz z Hubertem Izdebskim (autorem drugiej ustawy warszawskiej), jako eksperci wielokrotnie i z dużym zaangażowaniem wypowiadali się publicznie w sprawie zmian ustrojowych, oddziałujących na funkcjonowanie stolicy. W ostatnich latach warszawską problematyka ustrojową zajmuje się naukowo Magdalena Niziołek ${ }^{4}$ oraz były, wieloletni burmistrz gminy Warszawa-Ursynów, Stanisław Faliński ${ }^{5}$.

\section{Inspiracje dla ukierunkowania modelowego ustroju Warszawy}

Od 1990 roku wśród warszawskich samorządowców, polityków i naukowców trwa dyskusja nad optymalnym dla Warszawy modelowym rozwiązaniem organizacyjnym. Wśród inspiracji, z którymi zetknąłem się w ramach pracy naukowej i aktywności społecznej, na pierwszy plan wysuwają się stolice zachodnich demokracji. Jedna z propozycji, która początkowo wyraźniej się przewijała się w dyskusji to przykład Paryża. Sądzę, że nie popełnię wielkiego nadużycia łącząc tę inspirację, chociażby z nazwiskiem byłego senatora Andrzeja Wielowieyskiego, zaangażowanego od początku transformacji w budowę demokratycznego samorządu w Polsce. Koncepcja paryska jest mi w dużej mierze bliska, tym bardziej, że pierwsze 10 lat budowy samorządu w Polsce charakteryzowało się optymistycznym otwarciem na decentralizację i upodmiotowienie gminnych społeczności lokalnych. Paryż rzeczywiście jest inspiracją ciekawą, ale nie w pełni adekwatną. Miasto wraz z sąsiednimi, licznymi, samodzielnymi i zarazem niewielkimi gminami stanowi potężną aglomerację, silnie oddziałującą na całą gospodarkę kraju. Układ osadniczy Warszawy to mniejsza liczba potencjalnych gmin (dzielnic) składowych i miast sąsiadujących oraz mniej spójny, mniej zwarty układ aglomeracyjny. W dyskusjach nad zmianą ustroju Warszawy w latach 2000-2002 wyraźniej zaczął przewijać się model Berlina. Stworzenie jednolitej, centralnie zarządzanej gminy, podzielonej na dzielnice, wydawało się atrakcyjne

2 Zob. H. Izdebski, M. Kulesza, Administracja publiczna. Zagadnienia ogólne, Warszawa 2004, s. 243.

3 Zob. J. Regulski, Samorzad III Rzeczypospolitej. Koncepcje i realizacja, Warszawa 2000, s. 206-209.

$4 \quad$ M. Niziołek, Problemy ustroju aglomeracji miejskich ze szczególnym uwzględnieniem Warszawy, Warszawa 2008.

$5 \quad$ S. Faliński, Warszawski samorzad terytorialny w latach 1990-2002. Geneza, ustrój, idee ustrojowe, aktywność, Warszawa 2013. 
z punktu widzenia zapanowania nad chaosem organizacyjnym, wynikającym ze sprzeczności pomiędzy interesami samodzielnych gmin warszawskich, które nie zawsze wydawały się skłonne do kooperacji. Specyfika Berlina jednak, też nie pozwala na zastosowanie pełnej analogii. Berlin nie tylko pełni funkcję stolicy Niemiec jako państwa federacyjnego, ale dodatkowo sam jest jednym z krajów związkowych, gdzie władze krajowe oraz samorządowe są zintegrowane. W dyskusji nad przyszłością samorządu warszawskiego rzadziej sięgano do wzorców anglosaskich, do Londynu czy do konstrukcji amerykańskiego samorządu. Nie bez znaczenia przy tym pozostają kwestie gospodarki komunalnej i zarządzania zasobem własności miejskiej. Model europejski, wszakże generalnie bardziej ukierunkowany jest na odmienny stosunek do własności, inwestowanie w tworzenie substancji, stanowiącej własność komunalną i zarządzanie nią. W modelu anglosaskim wytworzyła się pragmatyka organizowania i zamawiania usług dla mieszkańców gminy z mniejszym niż w Europie kontynentalnej zaangażowaniem na rzecz rozszerzania majątku.

Na początku 2016 roku, kolejną zmianę ustrojową dla Warszawy zapowiedział marszałek Sejmu RP, Marek Kuchciński. Byłaby to już czwarta ustawa o ustroju miasta stołecznego Warszawy po 1989 roku, a wliczając reformę administracyjną z 1998 roku, piąta poważna zmiana organizacyjna w funkcjonowaniu stolicy.

\section{Problem stosowania pojęcia ewolucji w interpretacji zmian organizacyjnych}

Przedstawiona w tytule „ewolucja” ustroju, w świetle analizy przyczyn dokonywanych modyfikacji systemowych, jest z semantycznego punktu widzenia sformułowaniem w pewnym sensie ,przewrotnym”, ponieważ staram się wykazać, że w istocie reformatorom systemu nie na ewolucji sensu stricte mogło tu zależeć. Nie mniej jednak, w tle podejmowanych rozważań, punktem odniesienia dla niniejszej analizy jest paradygmat postępu cywilizacyjno-kulturowego. Pojęcie ewolucji może być różnie rozpatrywane, w zależności od tego do jakiej dziedziny nauki ma zastosowanie. W naukach społecznych pojęcie ewolucji wiąże się raczej wyraźniej z rozwojem, zmianą progresywną, postępem i wielozadaniowością oraz złożonością coraz doskonalszych, usamodzielniających się form organizacyjnych. W takim ujęciu pojęcie ewolucji byłoby bliższe pojęciu decentralizacji. 
Na podstawie obserwacji tła politycznego, można z dużym prawdopodobieństwem założyć, że częste zmiany w organizacji funkcjonowania stolicy Polski były uzasadniane z wykorzystaniem pretekstu „usprawnienia” i „udoskonalenia". W sensie deklaratywnym, ówczesnym decydentom chodziło zapewne o reformatorskie wzniesienie się na wyższy poziom organizacyjny. Tymczasem szeroko zakrojone, kosztowne działania reorganizacyjne mogły być $\mathrm{w}$ istocie inspirowane doraźną kalkulacją i bieżącą grą polityczną, partyjną, której bardziej przyświecało jednak zdobycie i utrzymanie atrakcyjnych taktycznie pozycji z punktu widzenia interesów partyjnych. Trudno jest zatem wskazać na wyraźną kierunkowość zmian, skoro w jednym momencie służyły decentralizacji i upodmiotowieniu mniejszych elementów składowych, a w innym miały bardziej recentralistyczny charakter.

Warszawa wydaje się być miastem, w którym działalność partii politycznych wyraźniej przeplata się z działalnością samorządową niż w mniejszych miejscowościach, gdzie - w większości przypadków - partie polityczne w radach gmin nie mają swoich przedstawicieli. W stolicy, niezależnie od zmian ustrojowych, na poziomie wykonawczym (organ kolegialny czy wieloosobowy) i uchwałodawczym (samodzielne gminy czy tylko dzielnice), dominowała i wciąż się utrzymuje identyfikacja partyjna funkcjonariuszy publicznych pochodzących z wyboru. Tego typu identyfikacja jest na ogół charakterystyczna dla szczebla centralnego, a w szczególności dotyczy parlamentarzystów. Zjawisko to oznaczać może w dużej mierze, że uprawnieni do głosowania w wyborach samorządowych mieszkańcy Warszawy w przedstawianej im ofercie wyborczej dostrzegają bardziej komitety wyborcze partii politycznych niż bezpartyjnych społeczników i aktywistów. Nie bez znaczenia przy tym jest zapewne brak wyraźnych cech wspólnotowych u mieszkańców stolicy, które bardziej typowe byłyby dla ludności autochtonicznej, zamieszkującej od wielu pokoleń na zwartym, niewielkim terytorium. Identyfikacja polityczna i partyjna wydaje się tu zatem paradoksalnie bardziej „naturalna”.

\section{Dynamika zmian ustrojowych w stolicy}

Od początku transformacji systemowej w Warszawie, co kilka lat zmienia się ustrój. Najważniejsze zmiany w funkcjonowaniu miasta wyznaczyły: 1. ustawa z dnia 18 maja 1990 roku o ustroju samorządu miasta stołecznego 
Warszawy $^{6}$, 2. ustawa z dnia 25 marca 1994 roku o ustroju m.st. Warszawy ${ }^{7}$, 3. reforma terytorialna $\mathrm{z} 1998^{8}$, 4. ustawa $\mathrm{z}$ dnia 15 marca 2002 roku o ustroju miasta stołecznego Warszawy 9 .

Pierwsza ustawa warszawska z 1990 roku była znaczącym krokiem do decentralizacji i powołała do życia związek siedmiu wielkich dzielnic-gmin z własnymi radami i kolegialnymi zarządami, na czele z burmistrzami oraz radą miasta, która wybierała prezydenta i zarząd. Ustawa z 1994 roku pogłębiała tę decentralizację, zwiększono liczbę samodzielnych gmin do 11, $\mathrm{z}$ tym że był to układ specyficzny, z wielką, podzieloną na dzielnice gminą Warszawa-Centrum i mniejszymi, samodzielnymi gminami tzw. wianuszka. Sytuację organizacyjną miasta skomplikowała jeszcze bardziej wprowadzona przez rząd Jerzego Buzka (koalicji AWS i UW) reforma administracyjna państwa, która zaczęła obowiązywać od 1999 roku. Wprowadzono wówczas trójszczeblowy samorząd terytorialny, w ramach którego obok gmin pojawiły się powiat i województwo. W tym modelu paradoksalnie Warszawa nie stała się jednak miastem na prawach powiatu. W istocie przypominała bardziej byt organizacyjny, podobny do niegdysiejszego powiatu ziemskiego, z odrębną radą powiatu i kolegialnym zarządem ze starostą na czele. W tym okresie istotne znaczenie dla rozwoju miasta miały decyzje rządzącej koalicji Unii Wolności i Sojuszu Lewicy Demokratycznej (w okresie 2001-2002 znaczna część działaczy samorządowych UW zaangażowała się w tworzenie Platformy obywatelskiej RP, która niejako automatycznie kontynuowała koalicję z SLD). Koalicja ta określona została później przez przeciwników politycznych (i opisywana w licznych publikacjach) jako tzw. układ warszawski ${ }^{10}$. W tym czasie zauważalny był szybki rozwój stolicy, któremu, w czasie prezydentury Marcina Święcickiego i Pawła Piskorskiego, towarzyszyły nowe inwestycje, jak budo-

6 Ustawa z dnia 18 maja 1990 r. o ustroju samorządu miasta stołecznego Warszawy (Dz.U. z 1990 r. Nr 34, poz. 200).

7 Ustawa z dnia 25 marca 1994 r. o ustroju miasta stołecznego Warszawy (Dz.U. z 1994 r. $\mathrm{Nr} 48$, poz. 195).

8 Ustawa z dnia 24 lipca 1998 r. o wprowadzeniu zasadniczego trójstopniowego podziału terytorialnego państwa (Dz.U. z 1998 r. Nr 96, poz. 603) oraz ustawa z dnia 5 czerwca 1998 r. o samorządzie powiatowym (tekst jedn. Dz.U. z 2016 r., poz. 814).

9 Ustawa z dnia 15 marca 2002 r. o ustroju miasta stołecznego Warszawy (tekst jedn. Dz.U. z 2015 r., poz. 1438).

10 I. Szpala, Układ warszawski: „Coś takiego nie wysteppowało”, „Gazeta Wyborcza”, Warszawa, 24.07.2008 r., http://warszawa.wyborcza.pl/warszawa/1,95190,5486104,Uklad warszawski_Cos_takiego_nie_wystepowalo_.html (dostęp: 20.05.2016 r.) 
wa mostów, dróg i tuneli, rozbudowa metra. Szczególnie, w drugiej połowie kadencji 1998-2002 nastąpił istotny przełom w wyniku przedterminowych wyborów do rady gminy Warszawa-Centrum. Wówczas, do współrządzenia miastem, po dwóch latach działalności w opozycji, powrócił SLD w miejsce AWS, a warszawski lider, zwycięskiej wówczas formacji, Jan Wieteska został wybrany przez radę na funkcję burmistrza najbogatszej wtedy gminy w kraju. W okresie tym, w samorządzie miejskim, coraz wyraźniej rozszerzała się dyskusja (w dużej mierze inspirowana przez liderów partyjnych) na temat zasad i poziomu finansowania inwestycji i zadań o charakterze ogólnomiejskim przez poszczególne gminy wchodzące w skład związku. Dobrowolność partycypowania gmin ,wianuszka” w kosztach transportu miejskiego, czy budowy dróg i mostów miała okazać się swoistą ,piętą achillesową" zdecentralizowanej Warszawy. Największym inwestorem i zarazem podmiotem szczególnie zadłużonym i obciążonym wskutek rozmachu inwestycyjnego stała się wówczas gmina Warszawa-Centrum. Likwidacja dotychczasowych gmin (i połączenie w jedną gminę) stwarzała szansę oddalenia ryzyka przekroczenia dopuszczalnego poziomu zadłużenia, stworzenia znacznie większego budżetu oraz poprawy zdolności kredytowej samorządu warszawskiego. Brak konieczności uzgadniania wielkich przedsięwzięć ogólnomiejskich z przedstawicielami poszczególnych części składowych miasta miał usprawnić proces podejmowania decyzji.

\section{Zmiana ustrojowa a uwzględnianie europejskich standardów}

Jeszcze w toku prac parlamentarnych nad ustawą zauważono także problem braku przeprowadzenia adekwatnych konsultacji z mieszkańcami, wymaganych na mocy Artykułu 5 Europejskiej Karty Samorządu Lokalnego ${ }^{11}$. Zadaniem tym w dość oryginalny sposób zajęła się kancelaria Sejmu na polecenie marszałka, zamawiając jedynie sondaż opinii publicznej, aby wypełnić wymóg konsultacji społecznych. W sondażu respondenci byli pytani, czy są za ,poprawą" ustroju miasta poprzez połączenie gmin. Tę formę konsultacji ostro skrytykował burmistrz gminy Warszawa-Białołęka Jerzy Smoczyński we wniosku do Trybunału Konstytucyjnego z 5 czerwca 2002 roku o stwierdzenie niezgodności ustawy z dnia 15 marca 2002 roku o ustroju miasta stołecznego Warszawy z Konstytucją Rzeczypospolitej Polskiej oraz Europejską Kartą

11 Europejska Karta Samorządu Lokalnego (Dz.U. z 1994 r. Nr 124, poz. 607). 
Samorządu Lokalnego. Burmistrz podkreślił: „Należy stwierdzić, że likwidacja gmin warszawskich i także gminy Warszawa-Białołęka nastąpiła bez konsultacji z mieszkańcami i bez zasięgnięcia opinii społeczności lokalnych (gmin), co stanowiło obowiązek Ustawodawcy na gruncie art. 5 i art. 4 ust. 6 Karty. Tryb ten nie został dochowany, w szczególności nie można za taki uznać internetowego sondażu opinii publicznej przeprowadzonego przez Marszałka Sejmu"12.

Zgodna z tym wnioskiem była dołączona opinia profesora Jacka Jagielskiego z Wydziału Prawa i Administracji Uniwersytetu Warszawskiego a także jego wydziałowego kolegi profesora Michała Kuleszy. Podobne wnioski - bezowocnie - złożyły gminy tzw. wianuszka warszawskiego: Warszawa-Ursynów, Warszawa-Rembertów, Warszawa-Wawer, Warszawa-Wilanów, Warszawa-Targówek, Warszawa-Bielany, Warszawa-Włochy, Warszawa-Ursus. Nie ulega wątpliwości, że przy wprowadzaniu ostatniej reformy nie dopełniono wystarczająco wymogu przeprowadzenia konsultacji z mieszkańcami likwidowanych gmin w zgodzie w Europejską Kartą Samorządu Lokalnego (na co zwrócił uwagę Trybunał Konstytucyjny), a wymóg konsultacji został ograniczony do przeprowadzenia sondażu na niewielkiej próbie mieszkańców. Jednak mimo licznych zastrzeżeń co do sposobu wprowadzania nowej ustawy Trybunał, rozpatrując wnioski likwidowanych gmin ,wianuszka” warszawskiego o stwierdzenie niekonstytucyjności ustawy z 2002 roku, nie dostrzegł problemu w recentralizacji miasta, w istocie uznając ,pragmatyczne" argumenty na rzecz skuteczności zarządzania za istotniejsze niż te, które wynikają z idei upodmiotowienia wspólnot lokalnych ${ }^{13}$. Ważny moment odwrotu od europejskich wartości decentralizacyjnych na przykładzie ostatniej reformy ustrojowej stolicy podkreśla Stanisław Faliński pisząc: „Ostatecznie państwo polskie wycofało się z formuły zdecentralizowania władzy publicznej w największym polskim mieście, wprowadzając Ustawę o ustroju miasta stołecznego Warszawy z dnia

12 Wniosek Burmistrza Gminy Warszawa-Białołęka z dnia 5 czerwca 2002 r. wraz z uchwałą Nr LV/723/02 Rady Gminy Warszawa-Białołęka z dnia 24 maja 2002 r., w sprawie wystąpienia z wnioskiem do Trybunału Konstytucyjnego o stwierdzenie niezgodności ustawy z dnia 15 marca 2002 r. o ustroju miasta stołecznego Warszawy z Konstytucją Rzeczypospolitej Polskiej oraz Europejską Kartą Samorządu Terytorialnego, „Samorząd Terytorialny", 2003, nr 7-8, s. 40-41.

13 Wyrok Trybunału Konstytucyjnego z dnia 18 lutego 2003 r. w sprawie zgodności z Konstytucją oraz Europejską Kartą Samorządu Terytorialnego ustawy z dnia 15 marca 2002 roku o ustroju miasta stołecznego Warszawy, K 24/02, „Orzecznictwo Trybunału Konstytucyjnego Zbiór Urzędowy” 2003, nr 2A, poz. 11; Dz.U. Nr 38, poz. 334 z dnia 6 marca $2003 \mathrm{r}$. 
15 marca 2002 r. ustrój scentralizowany decyzyjnie i finansowo z częściowym rozproszeniem władzy w sensie wykonawczo-politycznym i wprowadzeniem systemu stwarzającego pozory podejmowania decyzji dotyczących wspólnot lokalnych na poziomie lokalnym, w dzielnicach"14.

Konstatacja ta potwierdza, że w 2002 roku nastąpił przełom polityczny i organizacyjny w postrzeganiu systemowej roli samorządu lokalnego, którego jaskrawym przejawem była zmiana ustroju stolicy, stanowiąca swoisty odwrót od zainicjowanego w 1990 roku procesu decentralizacji władzy publicznej.

\section{Trudności w funkcjonowaniu samorządu po wprowadzeniu reformy z 2002 roku}

W 2002 roku doszło do najpoważniejszej zmiany ustrojowej, w wyniku której doprowadzono do recentralizacji miasta, jako jednolitej gminy na prawach powiatu (likwidacja odrębnego powiatu warszawskiego) oraz utworzenia dzielnic, jako jednostek pomocniczych, pozbawionych osobowości prawnej. Dzięki równoczesnemu wprowadzeniu w 2002 roku bezpośrednich wyborów wójtów, burmistrzów i prezydentów miast, w Warszawie również utworzony został jednoosobowy organ wykonawczy (prezydent miasta), w istocie usytuowany hierarchicznie ponad wybieranymi przez rady dzielnic, kolegialnymi zarząami $\mathrm{z}$ burmistrzami na czele. Są to dziś nominalnie jedyni w kraju burmistrzowie, niebędący jednoosobowym organem władzy wykonawczej. Dzielnice zostały po raz pierwszy od $1990 \mathrm{r}$. tak wyraźnie ograniczone w kompetencjach i pozbawione osobowości prawnej. Rady dzielnic mają dziś jedynie opiniodawcze umocowanie, a ich uchwały (włącznie z opinią do projektu załącznika budżetowego dla Dzielnicy) nie są wiążące dla prezydenta rady miasta (ostatecznie przyjmującej uchwałę budżetową). W istocie jedyna, faktyczna, rzeczywista, z punktu widzenia skutku, uchwała rady dzielnicy o charakterze kreatywnym to powołanie i odwołanie zarządu dzielnicy. Członkowie zarządów działają już, przede wszystkim, w zakresie pełnomocnictw udzielonych przez prezydenta miasta.

Swoisty dualizm organizacyjny wynikający, z jednej strony z ustawy o samorządzie gminnym, a z drugiej strony z ustawy o ustroju miasta stołecznego Warszawy z 2002 roku powoduje, że funkcjonariusze publiczni działający na obszarze warszawskich dzielnic w pewnych kwestiach są traktowani jak

14 S. Faliński, Warszawskie warianty. Zrealizowane i niezrealizowane koncepcje ustroju Warszawy w latach 1990-2002, Siedlce 2013, s. 282. 
przedstawiciele organów gminnych, którym przypisano ciężar odpowiedzialności decyzyjnej, a w innych już jako niewiele znaczące (z punktu widzenia procesu decyzyjnego) ogniwo pomocnicze wspierające działalność prezydenta i rady miasta. Zgodnie z przywołaną ustawą o ustroju miasta stołecznego Warszawy, rady dzielnic jedynie opiniują projekty uchwał rady miasta w zakresie, który ich dotyczy, a ich opinia wyrażona w formie uchwały ma charakter niewiążący. Podobnie zarządy dzielnic, poszczególni członkowie zarządów i burmistrzowie nie mogą podejmować wielu decyzji (w tym kadrowych w stosunku do pracowników urzędów dzielnic oraz majątkowych) bez stosownych upoważnień i pełnomocnictw o charakterze konstytutywnym, podpisanych przez prezydenta miasta. Chociażby sprawy kadrowe (zatrudnienia, zwolnienia, ustalanie wysokości wynagrodzenia pracowników, a nawet udzielanie urlopów wypoczynkowych) nie muszą być przekazane do realizacji burmistrzom dzielnic. Zarządy dzielnic w przypadku np. politycznej rywalizacji z prezydentem miasta mogą zatem zostać ograniczone jedynie do realizacji upoważnień o charakterze deklaratoryjnym, w ramach których prowadzą działalność, wynikającą jedynie z ustawowo i statutowo określonych kompetencji przypisanych organom dzielnic. Znaczna cześć możliwości działania zarządów jest uzależniona od uznaniowej i arbitralnej decyzji prezydenta miasta, co przy znacznym upolitycznieniu, upartyjnieniu warszawskiej sceny samorządowej budzi kontrowersje. W Warszawie, w każdej kadencji od 2002 roku, miały miejsce przypadki nieudzielania (lub ograniczonego udzielania) przez prezydenta upoważnień członkom zarządów dzielnic warszawskich, których skład polityczny miał charakter opozycyjny w stosunku do formacji reprezentowanej przez prezydenta. W nowym ustroju stolicy pojawił się problem nieuznawania lub ograniczania przez prezydenta (np. z przyczyn politycznych, ambicjonalnych, z braku zaufania) zarządu dzielnicy, wybranego przez daną radę. Przykładem może być chociażby nieudzielenie pełnomocnictw zarządowi dzielnicy Wawer w okresie prezydentury Lecha Kaczyńskiego, ograniczenie upoważnień dla zarządu dzielnicy Ursynów w drugiej kadencji Hanny Gronkiewicz-Waltz, czy odmowa nieudzielenia pełnomocnictw zarządowi dzielnicy Bemowo w trzeciej kadencji prezydentury Hanny Gronkiewicz-Waltz. Prezydent miasta, w skrajnym przypadku, w istocie zarządzać mógł dzielnicą wyznaczając własnych pełnomocników, działających obok wybranego przez radę dzielnicy zarządu, którego członkowie bywali nawet pozbawiani możliwości wydawania poleceń pracownikom urzędu dzielnicy, gdyż ci w istocie podlegają prezydentowi. 
Niektórzy badacze problematyki samorządowej mniej lub bardziej szczegółowo dostrzegają patologiczny wymiar funkcjonowania tego tworu ustrojowego. Henryk Gawroński i Izabela Seredocha w swojej analizie koncentrują się szczególnie na ustroju samorządowym Warszawy zaznaczając: „Poza typowym ustrojem: rada miasta - 60 radnych i prezydent miasta, każda z 18 dzielnic Warszawy posiada własną radę dzielnicy w składzie od 15 do 28 radnych. Pełnią one jedynie doradcze funkcje w zakresie zarządzania szkołami i własnością miejską na podległym im obszarze i uchwalają projekt części budżetu dotyczący dzielnicy. Władzę wykonawczą w dzielnicach sprawują burmistrzowie oraz od 2 do 4 wiceburmistrzów. Taki ustrój sprawia wrażenie, że mająca cechy powiatu dzielnica podporządkowana jest gminie"15.

Jest sporo racji w cytowanej opinii, choć nie sposób akurat zgodzić się tu $\mathrm{z}$ autorami, uznającymi, że dzielnice warszawskie mają cechy powiatu, ponieważ są przecież wyłącznie jednostkami pomocniczymi, nie posiadają osobowości prawnej, a uchwały rad dzielnic mają na ogół status opiniodawczy. Wielu burmistrzów dzielnic niejednokrotnie wyraża na sesjach rad dzielnic bezsilność z powodu nieudanej konfrontacji interesu reprezentowanej przez nich jednostki z działaniami scentralizowanego miasta. Okazuje się bowiem, że w praktyce przegrywają w sporze z dyrektorami biur miejskich, nie mówiąc już o prezydencie, czy radzie miasta. Krótko mówiąc, funkcjonariusze publiczni pochodzący z wyboru mają w praktyce mniejsze znaczenie niż pracownicy samorządowi zatrudnieni na stanowisku dyrektora miejskiego biura. Na jednej z sesji rady dzielnicy Targówek w 2010 roku wdałem się w dyskusję z burmistrzem, który w swoistym akcie bezradności tłumaczył radnym, rozczarowanym jego nieskutecznością, że w mieście stołecznym ma on zaledwie taki zakres władzy, jaki posiada sołtys na wsi. Burmistrz ten jednak, w dyskusji uznał moją argumentację wskazującą na znacznie większe ograniczenie decyzyjne i przyznał, iż w rzeczywistości ma jeszcze mniejsze znaczenie, gdyż sołtys pełni swoją funkcję jednoosobowo, a burmistrz dzielnicy warszawskiej jest zaledwie członkiem kolegialnego zarządu dzielnicy będącej zaledwie jednostką pomocniczą. Opisane zdarzenie obrazuje problematyczność funkcjonowania samorządu warszawskiego w segmentach zarządzania, które co prawda potencjalnie zdają się być najbliżej mieszkańców, ale jednocześnie nie mają adekwatnych instrumentów

15 H. Gawroński, I. Seredocha, Patologie w relacjach między sferami władzy publicznej oraz między organami, [w:] P.J. Suwaj, D.R. Kijowski (red.), Patologie w administracji publicznej, Warszawa 2009, s. 532. 
prawnych, organizacyjnych i finansowych, aby odpowiadać na ich potrzeby, tak jak ma to miejsce w samodzielnych, samorządnych i posiadających osobowość prawną gminach.

\section{Zagrożenia dla stabilności organizacyjnej w perspektywie nowej reformy}

Dodać należy, że w 2002 roku zmniejszono ustawową liczbę radnych w Polsce, co bardzo wyraźnie „spłaszczyło" normę przedstawicielską w Warszawie. Chociażby w znanej mi szczególnie gminie Warszawa-Targówek (mającej ponad 120 tys. mieszkańców) gdzie do 2002 roku było 45 radnych, wyraźnie można było odczuć dyskomfort pracy, gdy ich liczba została ograniczona zaledwie do 25. Po wyborach samorządowych w 2002 roku zaistniała tu konieczność likwidacji niektórych komisji merytorycznych ze względu na problem ze skompletowaniem minimalnego składu. Zmiana taka nie mogła być też obojętna dla częstotliwości kontaktów mieszkańców z radnymi oraz dla jakości wykonywanej działalności w okręgu wyborczym.

Wśród zagrożeń dla stabilności samorządowej Warszawy warto zwrócić uwagę na następujące problemy:

- zmiana ustroju może być wykorzystywana jako pretekst do obsady stanowisk (rozwiązanie umów z pracownikami zlikwidowanej struktury organizacyjnej, co miało już miejsce w 2002 roku)

- funkcja prezydenta m. st. Warszawy (silny, atrakcyjny politycznie) jednoosobowy organ wykonawczy, wyłoniony w wyniku wyborów bezpośrednich, może być wykorzystywana jako swoista „trampolina” dla dalszej kariery politycznej (przykład prezydentury Lecha Kaczyńskiego z 2005 roku).

- paradoks znacznego wzrostu liczby urzędników, nawet w urzędach dzielnic będących do 2002 roku urzędami samodzielnych gmin, których zadania wskutek ostatniej reformy zostały poważnie ograniczone na rzecz biur i delegatur urzędu miasta, co w istocie przypomina działanie prawa Parkinsona.

- biura urzędu miasta i ich delegatury tworzą w praktyce swoistą strukturę nadrzędną nad wydziałami urzędów dzielnic, co wydłużać może proces decyzyjny w ramach uzgodnień i konsultacji, szczególnie w przypadku braku nadania przez prezydenta miasta określonych upoważnień dla burmistrzów i członków zarządów dzielnic. 
Wydaje się, że w ostatniej reformie ustroju stolicy poprzez likwidację samodzielnych, samorządnych gmin, jednak zaprzepaszczono szansę na budowę podmiotowej, gminnej wspólnoty lokalnej. Być może, lepszym rozwiązaniem byłoby obligatoryjne, ustawowe zobowiązanie gmin warszawskich do finansowania zadań ogólnomiejskich według czytelnych reguł dotyczących poszczególnych obciążeń, czy też odpowiednie wydzielenie części zadań poza układ zadań gminnych, niż całkowita likwidacja podmiotowości prawnej gmin.

Zapowiadana, nowa ustawa, jeśli nie będzie w istocie nastawiona na synekury polityczne, zwolnienia i zatrudnienie nowych pracowników, to być może stworzy szansę odbudowania samodzielnych, podmiotowych gmin z osobowością prawną i własnym budżetem oraz odbudowę (budowę) lokalnej identyfikacji wspólnotowej na poziomie zlikwidowanych w 2002 roku gmin, obecnych dzielnic. Jednocześnie jeżeli zadania o charakterze ogólnomiejskim (główne drogi, mosty, kanalizacja, wodociągi, komunikacja miejska itp.) znajdą się w zakresie przedmiotowym działalności nowego województwa warszawskiego, to nie będzie zagrożenia paraliżu decyzyjnego i organizacyjnego miasta złożonego z samodzielnych, samorządnych gmin. Dodatkowo, istnieje niepowtarzalna szansa budowy aglomeracji warszawskiej z ościennymi miastami (w ostatnich latach wciąż bardzo rozrastającymi się i rozbudowującymi), przyległymi coraz wyraźniej do Warszawy, co może wpłynąć na usprawnienie komunikacji drogowej i usług transportowych. Gminy sąsiednie, w naturalny sposób, stają się nie tylko częścią aglomeracji warszawskiej, co swoistym przedłużeniem samej Warszawy, w związku z tym podtrzymywanie ich przynależności do odrębnych powiatów może w przyszłości zakłócać tendencje rozwojowe tego obszaru kraju. Oczywiście każda nowa reforma niesie ze sobą pewne koszty, pojawiają się też pytania i wątpliwości, co do ewentualnych zagrożeń związanych z podziałem województwa mazowieckiego. Nie bez znaczenia jest tu konieczność zabezpieczenia realizacji inwestycji planowanych ze środków Unii Europejskiej w perspektywie finansowej 2014-2020. Zasadne wydają się też obawy wyrażane przez obecne władze województwa mazowieckiego o zagrożeniu dla stabilności finansowej Mazowsza po ewentualnym wydzieleniu organizacyjnym Warszawy. Reforma ustrojowa stolicy w połączeniu z podziałem województwa wydaje się bardzo ryzykowną operacją. Z pewnością zmiana nie może się sprowadzać wyłącznie do prostych rozwiązań o charakterze administracyjnym, na bazie istniejących schematów. Nowe zmiany ustawowe w mojej ocenie mają szansę powodzenia pod warunkiem przeprowadzenia 
gruntownej analizy, szerokich konsultacji, zaangażowania ekspertów, głębszego namysłu i poświecenia dłuższego czasu pracom parlamentarnym, niż miało to miejsce w przypadku poprzednich regulacji.

\section{Literatura}

1. Augustyniak M., Jednostki pomocnicze gminy, Wolters Kluwer, Warszawa 2010.

2. Faliński S., Warszawski samorzad terytorialny w latach 1990-2002. Geneza, ustrój, idee ustrojowe, aktywność, Difin, Warszawa 2013.

3. Faliński S., Warszawskie warianty. Zrealizowane i niezrealizowane koncepcje ustroju Warszawy w latach 1990-2002, Uniwersytet Przyrodniczo-Humanistyczny w Siedlcach, Siedlce 2013.

4. Gawroński H., Seredocha I., Patologie w relacjach między sferami władzy publicznej oraz między organami, [w:] P.J. Suwaj, D.R. Kijowski (red.), Patologie w administracji publicznej, Wolters Kluwer, Warszawa 2009, s. 519-541.

5. Izdebski H., Kulesza M., Administracja publiczna. Zagadnienia ogólne, Liber, Warszawa 2004.

6. Izdebski H., Ustawa z dnia 25 marca 1994 r. o ustroju miasta stołecznego Warszawy. Tekst z komentarzem, Omnia, Warszawa 1994.

7. Jagielski J., ,, Ustawa warszawska” - prawo niedoskonałe (uwagi na marginesie wdrażania ustawy z 15 marca 2002 r. o ustroju m.st. Warszawy), ,Samorząd Terytorialny” 2002, nr 12, s. 59-67.

8. Mazuryk M., O ustroju miasta stolecznego Warszawy w latach 1990-2010, [w:] M. Mazuryk, S. Jaśkiewicz (red.), Administracja publiczna w III RP. Dwie dekady doświadczeń, Wydawnictwo Idealit, Warszawa-Siedlce 2011, s. 269-283.

9. Niezgódka-Medek M., Jak nie należy pisać prawa (uwagi na temat formalnoprawnej strony ustawy o ustroju miasta stołecznego Warszawy), „Samorząd Terytorialny” 1995, nr 4, s. 38-43.

10. Niziołek M., Problemy ustroju aglomeracji miejskich ze szczególnym uwzględnieniem Warszawy, Wolters Kluwer, Warszawa 2008.

11. Regulski J., Samorzad III Rzeczypospolitej. Koncepcje i realizacja, Wydawnictwo Naukowe PWN, Warszawa 2000.

12. Szpala I., Układ warszawski: „, Coś takiego nie wystepowało”, „Gazeta Wyborcza”, Warszawa, 24.07.2008 r.

13. Zawadzka B., Ustawa warszawska do poprawki!, „Wspólnota” 1994, nr 52-53.

Sebastian Kozlowski

Uniwersytet Warszawski 